\title{
An Initial Research: The Level of Environmental Awareness and Knowledge among Homestay Operators in Selangor, Malaysia
}

\author{
Yusnita Yusof, Normadihah M. Aminuddin
}

\begin{abstract}
Malaysia is a popular tourist destination in Southeast Asia. An increase of tourist arrivals (both domestic and international visitors) to Malaysia has seen a yearly increase in the number of accommodation available, especially those that are environmentally friendly. However, being environmentally friendly is a challenge for the tourism industry, especially when involving the accommodation sector. This is evidenced by the findings of a previous study that issues related to environmental sustainability are among problems faced by homestays in Malaysia. Since environmental awareness has been increasing across the world, these issues are important aspects that should be explored, especially relating to the tourism industry and specifically in the accommodation sector. Therefore, the purpose of this study is to examine the level of environmental awareness and knowledge among homestay operators in Selangor, Malaysia. In this preliminary study, 100 respondents were involved, who were selected using simple random sampling among homestay operators in Selangor, Malaysia. The descriptive analysis was done using SPSS software. The results show that the mean value for environmental awareness and knowledge is good. This shows that there is a high level of awareness and knowledge among homestay operators.
\end{abstract}

Index Terms: Environmental awareness, environmental knowledge, operator, homestay program, Malaysia.

\section{INTRODUCTION}

A homestay is a form of community-based tourism that offers a taste of local experiences to tourists [1]. Through this program, tourists will not only experience the village lifestyle but also have the chance to build close relationships with the families who welcome them into their homes and treat them as family members. They will also enjoy various exciting life experiences in the village [2], interact with the locals and gain experience, all the while learning the culture of rural communities. The tourists can experience the peacefulness of the village atmosphere and enjoy the diversity of local delicacies and traditional food in Malaysia. Visitors also have the opportunity to learn how to cook traditional Malaysian dishes. In addition, visitors can learn about Malay customs as well as traditional games and activities. In general, the main concepts emphasised in this tourism product are more on lifestyle travel and experience [1].

The Ministry of Culture, Arts and Tourism Malaysia (now known as the Ministry of Tourism Malaysia) introduced this

Revised Manuscript Received on July 10, 2019.

Yusnita Yusof , Faculty of Economics and Management Sciences, Universiti Sultan Zainal Abidin, Gong Badak Campus, 21300 Kuala Nerus, Terengganu, Malaysia.

Normadihah M. Aminuddin Faculty of Applied Social Sciences, Universiti Sultan Zainal Abidin, Gong Badak Campus, 21300 Kuala Nerus, Terengganu, Malaysia. program in 1988 as an alternative form of accommodation for tourists [3]. This program was then officially launched in 1995 by the Ministry of Culture, Arts and Tourism Malaysia in Temerloh, Pahang. The program, under the Rural Tourism Master Plan, aims to increase the involvement of rural communities in the tourism sector [4]. Lately, the homestay program is receiving more attention [5]. Up until March 2018, there are 209 homestay clusters and 4025 entrepreneurs who are registered with the Ministry of Tourism Malaysia; 16 of the homestays are located in Selangor, Malaysia. This is illustrated in Fig. 1 [6].

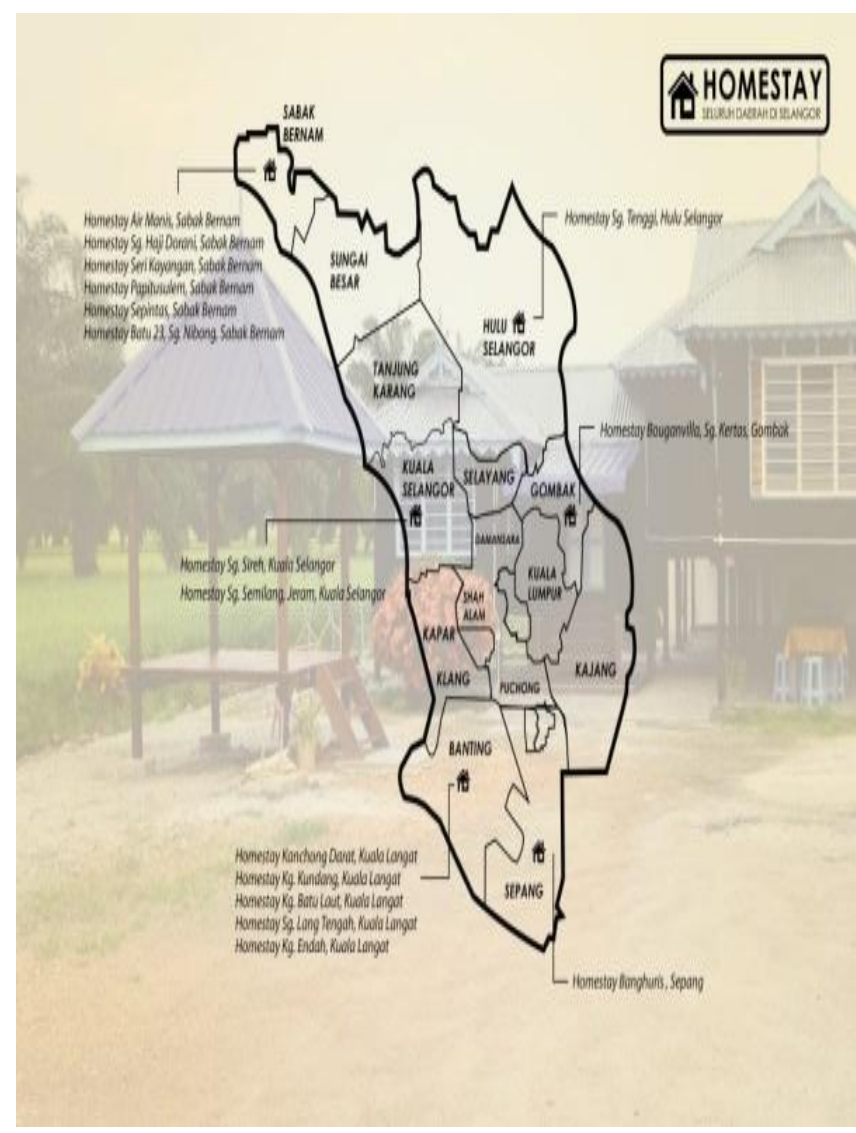

Fig. 1: List of homestays in Selangor up until March 2018

The hotel and accommodation sector is a sector in the tourism industry that contributes to environmental issues, especially during production and through day-to-day

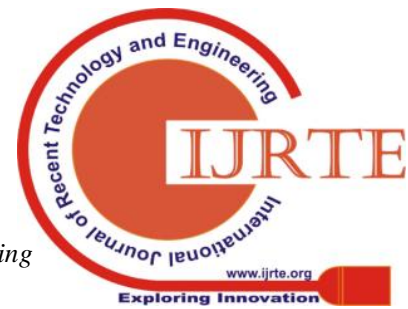




\section{AN INITIAL RESEARCH: THE LEVEL OF ENVIRONMENTAL AWARENESS AND KNOWLEDGE AMONG HOMESTAY OPERATORS IN SELANGOR, MALAYSIA}

operations which involve the usage of many resources, such as water and energy [7], [8]. In [9] point out that hotel and accommodation industries are pressed from some parties, such as customers, stakeholders and governments, to be more environmental friendly. In this industry, it is important to minimise any negative experiences by customers, as customers usually share negative impressions faster than the positive points, which will affect the image of a particular accommodation and hinder it from attracting new customers [10]. Due to the increase in environmental awareness and the demand for eco-friendly tourism, most countries are working to support green tourism through green practices [11]-[13]. They contended that green tourism has an important role in the environmental management system, especially the practices that are able to reduce the negative effect on the environment [14], [15] and to support its vital growth [16]. Terms like green practices, environmental management practices and eco-marketing practices are new approaches to marketing and are a valueadded approach for organisations [17]. In the hotel industry, green practices can be defined as the implementation of appropriate programmes and activities undertaken, as well as influenced by management to reduce the negative impact on the environment [18]-[20]. This approach not only adapts or reinforces existing approaches, but also searches for different perspectives, while at the same time addressing the gap to minimise negative impacts on ecology and society [21].

In [22] showed seven driving factors for solid waste management such as recycling and composting, awareness and education, economic motivation, marketing motivation, social motivation, legal pressure and networking. There are some past researchers who used awareness and knowledge variables in their studies. For example, studies conducted by [23] to identify the relationship between environmental awareness, knowledge and attitude among secondary school students found that there was a significant but not very strong relationship between awareness and knowledge. Awareness of the environment has a broad meaning. It does not only imply knowledge regarding the environment but also the attitudes, values and skills needed to solve environmental problems. In addition, environmental awareness is the first step towards more responsible behaviour [24]. Nurturing environmental awareness is deemed an important goal in the context of today's education because it is interdependent between humans and nature [25], [26].

Research by the United Nations Development Program Malaysia [27] on the factor of low awareness on environmental issues found that the causal factors include lack of education, lack of environmental knowledge, and inadequate media roles to disseminate this issue. In [28] also identified some obstacles to implementing green practices in the hotel and accommodation industries, such as lack of knowledge among hoteliers or homestay operators on environmental issues and strategies, managerial attitudes, employee support, financial problems, customer attitudes, operations and the law. Knowledge of the environment is a term used to imply knowledge of environmental issues and probable ways to solve the problem [29].
Based on previous research findings, it is clear that environmental awareness and knowledge is an important topic to be discussed when it relates to the sustainability development. Thus, at this preliminary stage, this research attempts to investigate the level of environmental awareness and environmental knowledge among homestay operators in Selangor, Malaysia.

\section{METHODOLOGY}

This pilot study involved homestay operators in Selangor, Malaysia. 100 respondents were selected for this study using simple random sampling. Data were analysed using Statistical Package for the Social Sciences (SPSS) software. Since the pilot study is the preliminary study for the whole research, thus at this stage, only one analyses were carried out, i.e. descriptive analysis.

\section{RESULTS AND DISCUSSION}

\section{Environmental Awareness}

The value for each item in the environmental awareness variable is summarised in Table 1. Based on the results, all the items showed good values. The item "I am aware that environmental awareness is important" showed the highest mean value (8.93) compared to the other items. This means that homestay operators now have a higher level of awareness on the importance of environmental care in their homestay. Meanwhile, the item "I will inform the authorities in case of environmental problems near my homestay" showed the lowest value (7.59). Although this value is still in considered good, this value indicates that homestay operators are less likely to report to authorities about their environmental problems. Instead, they prefer to ignore these problems.

Table 1: Level of environmental awareness

\begin{tabular}{|c|c|c|c|}
\hline No. & Item Statements & Mean & $\begin{array}{l}\text { Std. } \\
\text { Dev. }\end{array}$ \\
\hline 1 & $\begin{array}{l}\text { I will take action to improve the } \\
\text { environment in my homestay. }\end{array}$ & 8.6 & 1.524 \\
\hline 2 & $\begin{array}{l}\text { I will place recycling bins around } \\
\text { my homestay. }\end{array}$ & 7.87 & 1.889 \\
\hline 3 & $\begin{array}{l}\text { I am working hard to protect the } \\
\text { environment. }\end{array}$ & 8.74 & 1.454 \\
\hline 4 & $\begin{array}{l}\text { I am aware that environmental } \\
\text { awareness is important. }\end{array}$ & 8.93 & 1.444 \\
\hline 5 & $\begin{array}{l}\text { I know the impact of pollution on } \\
\text { animals and plants. }\end{array}$ & 8.77 & 1.53 \\
\hline 6 & $\begin{array}{l}\text { I am willing to contribute a small } \\
\text { portion of my income to } \\
\text { environmental care. }\end{array}$ & 7.79 & 2.258 \\
\hline 7 & $\begin{array}{l}\text { Environmental care problems are } \\
\text { a shared responsibility. }\end{array}$ & 8.72 & 1.676 \\
\hline 8 & $\begin{array}{l}\text { I am willing to sacrifice for the } \\
\text { environment. }\end{array}$ & 8.15 & 1.811 \\
\hline 9 & $\begin{array}{l}\text { I am willing to pay more to buy } \\
\text { eco-friendly products. }\end{array}$ & 7.32 & 2.146 \\
\hline 10 & $\begin{array}{l}\text { I gain more satisfaction if I can } \\
\text { take care of the environment. }\end{array}$ & & 1.484 \\
\hline
\end{tabular}




\begin{tabular}{|c|l|l|l|}
\hline 11 & $\begin{array}{l}\text { I love the environment but have } \\
\text { no time to practice related } \\
\text { activities (such as recycling, } \\
\text { composting, etc.). }\end{array}$ & 7.8 & 2.331 \\
\hline 12 & $\begin{array}{l}\text { I will inform the authorities in } \\
\text { case of environmental problems } \\
\text { near my homestay. }\end{array}$ & 7.59 & 2.408 \\
\hline 13 & $\begin{array}{l}\text { I am interested in participating in } \\
\text { environmental protection } \\
\text { programs. }\end{array}$ & 7.82 & 2.007 \\
\hline
\end{tabular}

\section{Environmental Knowledge}

Table 2 shows the value of each item for the environmental knowledge variable. Based on the 10 items, the statement "Preserving the environment is a commendable effort" indicated the highest mean value of 9.03. This showed that the respondents understand that efforts to preserve the environment are required and a necessary practice in the life of every individual. The lowest mean was for the statement "Non-recyclable equipment should be taxed." This indicated that from the respondents' perspective, they would not agree to be taxed if they use non-recyclable equipment. They argue that it would be additional high cost if they had to pay taxes on these items, which they consider are already costly. However, overall, the mean value for green image is good.

Table 2: Level of environmental knowledge

\begin{tabular}{|c|c|c|c|}
\hline No. & Item Statements & Mean & $\begin{array}{c}\text { Std. } \\
\text { Deviation }\end{array}$ \\
\hline 1 & $\begin{array}{l}\text { Preserving the environment is a } \\
\text { commendable effort. }\end{array}$ & 9.03 & 1.598 \\
\hline 2 & $\begin{array}{l}\text { I am aware that knowledge of } \\
\text { the environment is very } \\
\text { important. }\end{array}$ & 8.85 & 1.604 \\
\hline 3 & $\begin{array}{l}\text { I feel that the surrounding } \\
\text { pollution has affected my } \\
\text { quality of life. }\end{array}$ & 8.61 & 1.74 \\
\hline 4 & $\begin{array}{l}\text { Environmental issues have been } \\
\text { widely regarded internationally. }\end{array}$ & 8.53 & 1.766 \\
\hline 5 & $\begin{array}{l}\text { Local governments should do } \\
\text { something to raise ecological } \\
\text { awareness. }\end{array}$ & 8.79 & 1.578 \\
\hline 6 & $\begin{array}{l}\text { The government needs to spend } \\
\text { more on environmental } \\
\text { protection programs. }\end{array}$ & 8.91 & 1.602 \\
\hline 7 & $\begin{array}{l}\text { I pay attention to the effects } \\
\text { products I have purchased have } \\
\text { on the environment. }\end{array}$ & 8.39 & 1.675 \\
\hline 8 & $\begin{array}{l}\text { Non-recyclable } \\
\text { should be taxed. }\end{array}$ & 7.7 & 2.48 \\
\hline 9 & $\begin{array}{l}\text { The government has to } \\
\text { subsidise research in the } \\
\text { technology of recycling wasted } \\
\text { products. }\end{array}$ & 8.51 & 1.795 \\
\hline 10 & $\begin{array}{l}\text { Producers need to use recycled } \\
\text { materials in their operations. }\end{array}$ & 8.64 & 1.967 \\
\hline
\end{tabular}

\section{CONCLUSION}

The results from this initial study show that the mean value for environmental awareness and knowledge is good. This shows that there is a high level of environmental awareness and knowledge among homestay operators in Selangor, Malaysia. This means that the homestay operators have awareness and understanding of environmental conservation and working to protect the environment in the area where they live. It is hoped that further analysis will contribute to sustainability development in Malaysia, especially involving homestay programs.

\section{REFERENCES}

1. J, Mapjabil, S. A. Rosdi, M. Shuib, and S. Abdullah, "Pembangunan program homestay di Wilayah Utara Semenanjung Malaysia: Profil, produk dan prospek (Homestay programme development in the Northern Region of Peninsular Malaysia: Profile, products and prospects)," Geografia-Malaysian Journal of Society and Space, 7(2), 2017, pp. 45-54.

2. K. Kayat, and N. A. Nor, "Penglibatan ahli komuniti dalam program pembangunan komuniti: Satu kajian ke atas program homestay di Kedah (Community Members Involvement in Community Development Programme: Homestay Programme in Kedah)," Akademika, 67(1), 2006, pp. 77-102.

3. Ministry of Rural and Regional Development, Pengurusan homestay. 2010, Available: http://www.infra.gov.my/ web/guest/pengurusanhomestay.

4. Tourism Malaysia 2009 annual report. Putrajaya: Tourism Malaysia, 2010.

5. Ministry of Tourism Malaysia, Pengalaman homestay Malaysia. Kuala Lumpur: Ministry of Tourism Malaysia, 2011.

6. M. Chikita, Analyzing the impact on consumer satisfaction, behavior and attitudes by using eco-friendly practices and products in Surfers Paradise/Gold Coast city hotels, Australia. Bachelor thesis, Helsinki: HaagaHelia University of Applied Sciences, 2012.

7. N. Zengeni, D. M. Zengeni, and S. Muzambi, "Hoteliers' perceptions of the impacts of green tourism on hotel operating costs in Zimbabwe: The case of selected Harare hotels," Australian Journal of Business and Management Research, 2(11), 2013, pp. 64-73.

8. J. K. Lynes, and D. Dredge, "Going green: Motivations for environmental commitment in the airline industry. A case study of Scandinavian Airlines," Journal of Sustainable Tourism, 14(2), 2006, pp. 116-138.

9. S. S. Bhakar, S. Bhakar, and M. S. Bhakar, "Customer satisfaction or service quality-identifying mediating variable and evaluating behavioral intention model in hotel industry: An SEM approach," Research Journal of Social Science and Management, 5(2), 2015, pp. 111124

10. S. Ham, and H. Han, "Role of perceived fit with hotels" green practices in the formation of customer loyalty: Impact of environmental concerns," Asia Pacific Journal of Tourism Research, 18(7), 2013, pp. 731-748.

11. H. Hassan, and H. Nezakati, Selected Issues in Hospitality and Tourism Sustainability. Selangor: Universiti Putra Malaysia, 2014.

12. H. Nezakati, S. Moghadas, Y. A. Aziz, A. Amidi, R. Sohrabinezhadtalemi, and Y. Y. Jusoh, "Effect of behavioral intention toward choosing green hotels in Malaysia-Preliminary study," Procedia-Social and Behavioral Sciences, 172, 2015, pp. 57-62. 


\section{AN INITIAL RESEARCH: THE LEVEL OF ENVIRONMENTAL AWARENESS AND KNOWLEDGE AMONG HOMESTAY OPERATORS IN SELANGOR, MALAYSIA}

13. S. Lee, H. C. Honda, G. Ren, and Y. Lo, "The implementation of green tourism and hospitality," Journal of Tourism and Hospitality, 5(4), 2016, pp. 1-5.

14. M. Azam, and T. Sarker, "Green tourism in the context of climate change towards sustainable economic development in the South Asian region," Journal of Environmental Management and Tourism, 1(3), 2011, pp. 6-15.

15. M. Bhuiyan, C. Siwar, S. Ismail, and K. Adham, "Green tourism for sustainable regional development in East Coast Economic Region (ECER), Malaysia," OIDA International Journal of Sustainable Development, 5(7), 2012, pp. 69-78.

16. S. H. Kim, K. Lee, and A. Fairhurst, "The review of "green" research in hospitality, 2000-2014: Current trends and future research directions," International Journal of Contemporary Hospitality Management, 29(1), 2017, pp. 226-247.

17. A. A. Al-Shourah, The relationship between environmental management practices (EMP) and hotel performance: EMP drivers and the moderating role of perceived benefits. $\mathrm{PhD}$ thesis, Pulau Pinang: Universiti Sains Malaysia, 2007.

18. I. Mensah, "Environmental management practices among hotels in the greater Accra region," International Journal of Hospitality Management, 25(3), 2006, pp. 414-431.

19. H. L. Perera, and A. Pushpanathan, "Green marketing practices and customer satisfaction: A study of hotels industry in Wennappuwa divisional secretariat," Tourism, Leisure and Global Change, 2(1), 2015, pp. 1329.

20. M. K. A. Kamarudin, M. E. Toriman, N. A. Wahab, H. Rosli, F. M. Ata, and M. N. Faudzi, "Sedimentation study on upstream reach of selected rivers in Pahang River Basin, Malaysia," International Journal on Advanced Science, Engineering and Information Technology, 7(1), 2017, pp. 35-41

21. N. M. Abdullah, M. E. Toriman, H. M. Din, N. A. A. Aziz, M. K. A. Kamarudin, N. S. A. Rani, F. M. Ata, M. H. Saad, N. W. Abdullah, M. Idris, and N. R. Jamil, "Influence of spatial and temporal factors in determining rainfall interception at dipterocarp forest canopy, Lake Chini, Pahang," Malaysian Journal of Analytical Sciences, 17(1), 2013, pp. 11-23.

22. H. R. Radwan, E. Jones, and D. Minoli, "Solid waste management in small hotels: A comparison of green and non-green small hotels in Wales," Journal of Sustainable Tourism, 20(4), 2012, pp. 533-550.

23. Z. Aminrad, S. Z. Zakariya, A. S. Hadi, and M. Sakari, "Relationship between awareness, knowledge and attitudes towards environmental education among secondary school students in Malaysia," World Applied Sciences Journal, 22(9), 2013, pp. 1326-1333.

24. M. Sengupta, J. Das, and P. K. Maji, "Environmental awareness and environment related behaviour of twelfth grade students in Kolkata: Effects of stream and gender," Anwesa, 5(1), 2010, pp. 1-8.

25. M. E. Toriman, F. M. Ata, M. K. A. Kamarudin, and M. Idris, "Bed-load sediment profile and effect of river bank erosion on river cross-section," American Journal of Environmental Sciences, 9(4), 2015, pp. 292-300.

26. Y. Hadzigeorgiou, and M. Skoumios, "The development of environmental awareness through school science: Problems and possibilities," International Journal of Environmental and Science Education, 8(3), 2013, pp. 405-426.

27. N. R. Das, "Human development report 2007/2008 fighting climate change: Human solidarity in a divided world, UNDP, New York," Social Change, 39(1), 2009, pp. 154-159.
28. H. Doody, "What are the barriers to implementing environmental practices in the Irish hospitality industry," Tourism and Hospitality Research in Ireland Conference, 2010.

29. A. Zsóka, Z. M. Szerényi, A. Széchy, and T. Kocsis, "Greening due to environmental education? Environmental knowledge, attitudes, consumer behavior and everyday pro-environmental activities of Hungarian high school and university students," Journal of Cleaner Production, 48, 2013, pp. 126-138. 